\title{
ANALYSIS OF THE INFLUENCE OF MARKETING MIX TOWARDS LOYALTY THROUGH COOPERATIVE CUSTOMER SATISFACTION IN SOUTH TANGERANG CITY
}

\author{
SILVIA SARI ${ }^{1}$, SEVTY WAHIDDIRANI SAPUTRI ${ }^{2}$ \\ Accounting lecturer, Faculty of Economics, University of Pamulang \\ e-mail : dosen01387@unpam.ac.id
}

\begin{abstract}
Cooperative as an important pillar in economic development in Indonesia. Cooperatives need to improve their loyalty and customer satisfaction in order to win the competition with other rital businesses. The research aims to identify and analyze forming factors in customer satisfaction that contribute to customer loyalty. This research was conducted in South Tangerang City because there is an increase in the number of cooperative ventures. Primary data was collected through questionnaires to 100 cooperative customers in South Tangerang city with purposive sampling techniques, and data Analyzed with Structural Equation Modeling (SEM). The exogenous latent variable is the marketing Mix (7P). While customer satisfaction and loyalty as an endogenous latent variable. The results showed that the built model has fulfilled the criteria of goodness fit and variable measuring research has a reliability $(C R \geq 0.70, V E \geq 0.50)$ which is good. The results of SEM analysis indicate that customer satisfaction is largely influenced by the people dimension $(\gamma=0.92)$. The People dimension is well formed by the ability of employees to provide clear information $(\lambda=0.97)$, employee appearance $(\lambda=0.87)$, fast employee response $(\lambda=0.84)$, and employee friendliness ( $\lambda=0.57$ ). This the human resources (people) on cooperative ventures need to be built sustainably and gradually the customer satisfaction proved able to foster cooperative customer loyalty.
\end{abstract}

Keywords: Customer Satisfaction, Customer Loyalty, Marketing Mix, People, Cooverative

\section{INTRODUCTION}

\subsection{Background}

Cooperative as an important pillar in economic development in Indonesia. The growth of cooperatives in Indonesia began to decline. Cooperatives need to maintain customer satisfaction and loyalty to continue to grow and can win the competition with other ritail efforts. Cooperatives and SMES have proven tough. Cooperatives and SMES were able to survive in the economic crisis of 1998.

The people of the city of Tangsel improve their lives through cooperatives. 
The Government of the city of Tangsel also allowed anyone interested in forming cooperatives by providing assistance with the cost of notarial deed. Because of this, Tangsel is believed to be the city of cooperatives.

The Minister of Cooperatives and SMES of the Republic of Indonesia Anak Agung Gede Ngurah Puspayoga also appreciated the cooperative program in the city of Tangsel. It was disclosed in the inauguration ceremony of the 1,000 saving program per day in cooperatives. The inauguration of the Saving program was held in commemoration of city level cooperative day in the field ITC BSD, Sunday (detik.com 2017).

The number of cooperatives in South Tangerang increased from 371 in 2013 to 532 in 2014 and increased again 600 units in 2015. But this amount of increase will not persist if it is not in follow customer satisfaction and loyalty. The

Table 1. Growing number of cooperatives by Regency/city in

\begin{tabular}{|c|c|c|c|c|c|c|c|}
\hline \multirow{2}{*}{ Kabupaten/Kota } & \multicolumn{7}{|c|}{$\begin{array}{l}\text { Jumlah Koperasi Nenurut Kabupaten/Kota (Unii) } \\
\text { Jumlah }\end{array}$} \\
\hline & 2009 & 2010 & 2011 & 2012 & 2013 & 2014 & 2015 \\
\hline Kab Pandeglang & 862 & 867 & 873 & 838 & 839 & 584 & 498 \\
\hline Kab Lebak & 735 & 661 & 813 & 765 & 765 & 789 & 811 \\
\hline Kab Tangerang & 1381 & 945 & 945 & 945 & 1196 & 1273 & 1297 \\
\hline Kab Serang & 786 & 829 & 829 & 958 & 960 & 1013 & 1107 \\
\hline Kota Tangerang & 1006 & 1049 & 1049 & 1049 & 1128 & 1148 & 976 \\
\hline Kota Cilegon & 421 & 478 & 478 & 521 & 525 & 542 & 470 \\
\hline Kota Serang & 664 & 472 & 472 & 431 & 694 & 342 & 256 \\
\hline Kota Tangerang Selatan & - & 371 & 371 & 371 & 371 & 532 & 600 \\
\hline Provinsi Banten & 5855 & 5672 & 5672 & 5950 & 6550 & 113 & 127 \\
\hline
\end{tabular}

Source: BPS banten.go.id (processed)

following data on the number of cooperatives in South Tangerang in 2009-2015 can be seen in table 1 .

Based on the background above, researchers are interested in conducting a study in the field of marketing management in particular loyalty and customer satisfaction cooperatives with the title of research "Analysis of the influence of marketing mix towards loyalty through Customer satisfaction cooperative in South Tangerang City ".

\subsection{Goal}

In line with the background of problems, problem constraints, and the formulation of the problems posed above, this study has the following objectives:

1. Describe the contribution of the marketing mix-forming indicator to the cooperative customers. 
2. Analyzing the dimensions of marketing mix that affect the customer satisfaction of the cooperative.

3. Analyzing the impact of customer satisfaction on cooperative customer loyalty.

\section{LITERATURE REVIEW}

2.1. Cooperative According to law number 25 of 1992: "Cooperative is a business entity that consists of persons who are cooperatives or legal entities with the establishment of activities based on the principle of cooperatives as well as the economic movement of the people based on the principle Family ". Welfare members in accordance with the purpose of cooperatives are always cultivated in various ways in order to compete and maintain cooperatives in the midst of free market. Therefore, the creation of loyal members is indispensable and important for the growth of cooperatives in Indonesia.

\subsection{Marketing Mix}

Marketing Mix is a set of marketing tools that companies use to achieve objectives in the target market. Generally, the marketing mix has four basic principles or also called product mix that consists of $4 \mathrm{P}$, namely product, place, price, and promotion. The marketing mix has an extension that adds another $3 \mathrm{P}$ to the product mix, which is process, people, and physical evidence. By using the marketing mix, customers can evaluate overall good product quality, service quality, and price offered.

According to Kotler \& Amstrong (1999), the concept of traditional marketing mix consists of product, price, place and promotion, however, for marketing services need expanded marketing mix is by adding people, physical evidence, and process.

1. Product

Products according to Kotler \& Keller (1999) are everything that producers can offer to be noted, requested, sought, purchased, used or consumed markets as fulfillment of the needs or wishes of the market in question. Products are a set of complex satisfaction values. The product is also a combination of goods and services offered by the company to the target market (Kotler \& Amstrong 1999). The value of a product is determined by the buyer based on the benefits they will receive from the product.

2. Price

The price is the amount of money the customer must pay to acquire the product, or the total value that the consumer exchanges for the benefit of owning or using a product or service (Kotler \& Amstrong 1999). Price loggers are a critical point in the marketing mix because the price determines the income of a business or the businesses (Hurriyati 2005). The pricing decision is also very significant in the values/benefits that can be given to 
customers and plays an important role in the image of quality products and services. The tariff determination strategy in a company can use the premium tariff determination at the time of the highest demand and the discounted rate at the time of the request down (Kotler \& Amstrong 1999). In deciding to make a purchase back, the customer also assess whether the money they spend corresponds to the value they get (Zeithaml \& Bitner 2000).

3. Place

The place is interpreted as a company activity that makes products available to target customers (Kotler \& Amstrong 1999). The location relates to decisions made by the company regarding where the operation and its staff will be placed. It is important for the company to consider the location by considering the type of interaction between service providers and customers (Hurriyati 2005).

4. Promotion

Promotion is one of the defining factors of the success of a marketing program. Regardless of the quality of a product, if the consumer does not know the existence of the product and is not convinced that the product will be useful to them, then they will never buy it. Promotion is an activity that conveys the benefits of the product and persuades customers to buy it (Kotler \& Amstrong 1999). Promotion is also a form of marketing communication that reminds the target market of the company and its products to be willing to receive, buy, and be loyal to the products that the company offers in question (Hurriyati 2005).

5. People

According to Zeithaml \& Bitner (2000) People are all actors who play a role in the presentation of services so that it can affect the perception of buyers. This factor refers to the employee who produces and delivers the service. In an effort, there are many services involving personal interactions between customers and employees. All employees ' attitudes and actions, even the way employees dress and employee appearances have an influence on consumer perception or the success of service delivery (Hurriyati 2005). Personnel are also regarded as a key element in a customer organization (Kotler \& Amstrong 1999).

6. Physical Evidence Zeithaml \& Bitner (2000) argues that physical facilities are an environment that can form services for customers through physical goods facilitated by service providers, or can be said to be a real thing to influence Consumer decision to purchase and use the service products offered. Elements included in physical advice include physical environments, in which case physical buildings, equipment, fixtures, logos, colors and other items are joined together with services provided such as tickets, covers, labels, and more.

7. Process

According to Zeithaml \& Bitner (2000) The process is all actual procedures, mechanisms, and flow of activity used to deliver the services. The element of 
this process has the meaning of a company's efforts in carrying out and carrying out its activities to meet the needs and desires of consumers. The process pace and service provider skills are obviously needed to form the basis of his purchase satisfaction. Management needs to ensure availability and consistency of quality.

\subsection{Customer Loyalty}

In the business context, loyalty describes the willingness of customers to continue subscribing to a company in the long term, by purchasing and using goods and services on a recurring and exclusive basis, and voluntarily recommending Company's products/services to others (Lovelock et al. 2004). Furthermore, according to Griffin (2005), loyalty is a strong commitment from consumers to be willing to re-purchase the products and or services that are consistently liked in the long term. Reward from customer loyalty is long-term and cumulative. Loyal customers will make the purchase for a long time and increase.

Loyalty is a non-random re-purchase, meaning that the customer has a specific know what to buy and where to get the product/service. If a customer repurchases, the customer may not necessarily be categorized as a loyal customer. Raab et al. (2008) suggests that the reason why the customer re-purchase varies depending on the motive, namely:

\section{Situational}

Customer repurchase one of them due to situational motif. This relates to all external factors. For example a close distance or strategic place that makes it easy for customers to reach the location.

2. Contractual

There are contracts or certain conditions where certain customers benefit from repeated purchases to a company. However, when the profit has expired/expired the customer will end the purchase of the recurrence.

3. Economic

Customers make repeated purchases to the company because the products/services offered by the company provide a price that is appropriate to the economic condition of the customer or because the competitor has not been able to provide a lower price to the product/service Similar. Customers with such economic motives are not loyal customers.

4. Technical/Functional Customers make repeat purchases based on the perceived benefits of the product/service. Customers have a commitment to set their standards on the products/services that will be used at the beginning of the purchase. Changes to the brand will bring down its standards and face many new issues so that the customer decides to repurchase the same company.

5. Psychological 
In this motif, customer does not base their purchase based on material profit, but the customer feel the attachment with the company. Customers who make repurchases based on this motive, it is potentially a loyal customer.

\section{Customer Satisfaction}

Customer satisfaction is defined as a post-consumption evaluation focused on a particular product or service where the result of the evaluation was obtained through a comparison of pre-emptment with performance perception when and after Consume (Authority et al.). Achieving the highest level of customer satisfaction is a major goal faced by every company (Muala \& Qurneh 2012). Satisfied customers of a product will hold their commitment and return to buy consistently future and provide recombination for other prospective customers (Muala \& Qurneh 2012).

A customer will give a high value to a service when he/she feels the benefits are greater than the cost incurred, and other services of the competitor's service providers are not able to provide more benefits Good. If the company's performance is better than what the customer expects or is at least the same as expected, the customer will be satisfied (Kotler \& Keller 1999). If the company's performance is under customer expectation, the customer will be dissatisfied.

\section{RESEARCH METHOD}

\subsection{Data Collection Techniques}

The data used in this study is divided into two, namely primary data and secondary data which are qualitative and quantitative. Primary Data is collected from interviews and filling questionnaires on cooperative customers in South Tangerang city. Secondary Data obtained from BPS, library, Internet, cooperative office and other literature that can be used as reference material related to the research conducted.

\subsection{Operational Definitions of Variables}

A research variable is a concept that has value and can be measured. The variables to be used in this study consist of latent variables and manifest variables (indicators of the latent variables). Identification of latent variables (exogenous and endogenous) and manifest variables are presented in table 2 . 
Table 2. Identify the manifest variable for nine latent variables

\begin{tabular}{|c|c|c|}
\hline Xariabel Laten & Code & Yariabel Manifest \\
\hline \multirow[t]{3}{*}{ Product } & $\mathrm{X} 1$ & Fully Available Products \\
\hline & $\mathrm{X} 2$ & Attractive Cooperative Products \\
\hline & $\mathrm{X} 3$ & Quality Cooperative Products \\
\hline \multirow[t]{2}{*}{ Price } & $\mathrm{X} 4$ & Prices of products offered are affordable \\
\hline & $\mathrm{X} 5$ & Conformity between price and product quality \\
\hline \multirow[t]{3}{*}{$\begin{array}{l}\text { Process } \\
\end{array}$} & X6 & Responses to consumer complaints \\
\hline & $\mathrm{X} 7$ & Orders are always available \\
\hline & $\mathrm{X} 8$ & Payment transaction Speed \\
\hline \multirow[t]{3}{*}{ Promotion } & $\mathrm{X} 9$ & Promotion in social media \\
\hline & $\mathrm{X} 10$ & Clear and attractive signage \\
\hline & $\mathrm{X} 11$ & Word of mouth promotion \\
\hline \multirow[t]{4}{*}{ People } & $\mathrm{X} 12$ & Friendly and polite employees \\
\hline & $\mathrm{X} 13$ & Fast-responsive employees \\
\hline & $\mathrm{X} 14$ & Employees who provide clear information when asked \\
\hline & $\mathrm{X} 15$ & Neat employee appearance \\
\hline \multirow{5}{*}{ Place } & $\mathrm{X} 16$ & Strategic place and easily accessible \\
\hline & $\mathrm{X} 17$ & Cooperative hygiene \\
\hline & $\mathrm{X} 18$ & Cooperative Comfort Easy \\
\hline & $\mathrm{X} 19$ & to find layout \\
\hline & $\mathrm{X} 20$ & A cooperative display that attracts interest to visit \\
\hline \multirow[t]{5}{*}{ Physical Evidence } & $\mathrm{X} 21$ & Parking availability \\
\hline & $\mathrm{X} 22$ & Availability of trolley/shopping Cart Cooperative \\
\hline & $\mathrm{X} 23$ & Interesting cooperative Interior \\
\hline & $\mathrm{X} 24$ & Cooperative facilities (Wi-Fi, AC, TV, music, etc) \\
\hline & Y1 & $\begin{array}{l}\text { Based on experience, customer satisfied with the quality } \\
\text { of cooperative service }\end{array}$ \\
\hline \multirow[t]{5}{*}{ Customer Satisfaction } & $\mathrm{Y} 2$ & $\begin{array}{l}\text { Based on experience, customers are satisfied after } \\
\text { consuming cooperative products }\end{array}$ \\
\hline & Y3 & $\begin{array}{l}\text { Overall, the customer is satisfied to have made the } \\
\text { purchase at the cooperative }\end{array}$ \\
\hline & Y4 & Cooperatives meet customer expectations \\
\hline & Y5 & Customer will re-purchase to cooperatives \\
\hline & Y6 & $\begin{array}{l}\text { Customers are less sensitive to prices, and when there is } \\
\text { a hike, customers are immune to competitor store } \\
\text { withdrawals }\end{array}$ \\
\hline \multirow[t]{2}{*}{ Customer Loyalty } & Y7 & $\begin{array}{l}\text { Customers are willing to wait or come again if } \\
\text { cooperative products are empty }\end{array}$ \\
\hline & Y8 & $\begin{array}{l}\text { Customers provide recommendations to other parties to } \\
\text { visit cooperatives }\end{array}$ \\
\hline
\end{tabular}

\subsection{Sample Collection Techniques}

Sample withdrawal is performed in Purposive, the researcher selects and determines the respondents themselves as a sample unit based on the specific criteria that the researcher has determined. So at the time of sampling there were deliberate factors and did not accidentally take the respondents who were on site. Sample size used in SEM analysis tool using maximum likelihood estimation (MLE) range of 100 respondents (Ghazali 2008). So the samples taken in this study were 100 cooperative customers in several HIGH schools, SMK, and cooperatives at the university located in South Tangerang city. Some are in the form of school cooperatives and some have already shaped kopinmart. 


\subsection{Data Analysis Techniques}

The Data that has been collected is further analyzed quantitatively and qualitative. Qualitative analysis is done with a descriptive approach. Quantitative analysis was conducted with the structural equation model approach (Structural Equation models) with Microsoft Excel 2013 software and Linear Structural Relationship (LISREL) ver 8.30 to analyse activity and loyalty relationships of customers and the dominant factors that form it.

\section{RESULTS AND DISCUSSION}

\subsection{Describe the contribution of marketing mix-forming indicators to cooperative customers.}

The marketing mix variable consists of seven dimensions namely product, price, place and promotion, people, physical evidence, and process. Each contributionforming indicator of the marketing mix is described as follows :

\section{Product}

Varibel product has three forming indicators, namely product completeness attributes, attractive and product quality. These three indicators have the value $\mid \mathrm{t}$-Count $\mid$ Larger than $\mathrm{T}$ table (1.96), so it can be said that these three indicators have a significant contribution to the product variables. Interesting cooperative products have the greatest influence with the value of loading factor namely 0.89 . Cooperative products must have a characteristic, uniqueness and attraction of its own. This is what is a differentiator of products cooperatives with other retail products. Attractiveness is an important thing in determining customer loyalty and satisfaction. The value of a product is determined by the buyer based on the benefits they will receive from the product.

\section{Price}

Varibel Price has two forming indicators, which is the affordability attribute of product price and price suitability with product quality. Both of these indicators have the value | t-Count | Larger than T table (1.96), so it can be said that both of these indicators have a significant contribution to variable price. The suitability of the price with portions and quality of products has the greatest influence with the loading value of 1.27 factors. The affordability indicator of cooperative product price has a small value, which is less than 0.5 but is still stated enough in reflecting the price variable in this research because it has a loading factor of 0.47 . Wijanto (2008) states that if there is a standard factor or loading factor of the default <

0.50 , but still $\geq 0.30$ then the corresponding variable can still be said to have contributed to the variables. The customers are cooperative shopping in cooperatives not because the price in the cooperative is cheaper but they dare to buy at a slightly more expensive price if the quality they feel is also nicer.

\section{Process}

Varibel process has four forming indicators, namely attribute of response to consumer complaints, orders are always available and payment transaction speed. These four indicators have the value $\mid \mathrm{t}$-Count $\mid$ Larger than $\mathrm{T}$ table (1.96), so it can be said that these four indicators have a significant contribution to the process variable. Transaction speed indicators and orders are always available to have the greatest 
influence with the loading value of 0.92 and 0.93 factors. This is because cooperatives prioritize products that serve the needs of its members so that the product will suit the needs of customers. Indicators of response to consumer complaints have a small value, which is less than 0.5 so it is not enough to reflect the process variables in this research because it has a loading factor value of only 0.18 .

\section{Promotion}

Varibel Promotion has three forming indicators, namely social media promotion attributes, signboard, and word of mouth promotion. These three indicators have the value | t-Count | Larger than T table (1.96), so it can be said that these three indicators have a significant contribution to the promotion variable. Social media promotion indicators have the greatest influence with the loading value of 0.68 factors. This is because many of the respondents answered the promotion on social media most relevant to the present day compared to signage and word-ofgod' target='blank_' title='Entry of "word"'>word-of-mouth promotion. The promotional indicators of the word of mouth have a small value, which is less than 0.5 so it is not enough to reflect the promotion variables on this research because it has a loading factor value of only 0.22 . While the promotional signage still reflects the promotion variables on this research because it has a loading factor value of 0.3 is threshold of 0.22 .

\section{People}

Varibel people has four indicators of forming, namely attribute the friendliness of employees, fast the employee's response, clear information of employees and the grooming of the employee's appearance. These four indicators have the value $\mid \mathrm{t}$ Count | Larger than T table (1.96), so it can be said that these four indicators have a significant contribution to the promotion variable. Indicator employees are able to provide clear information having the most influence with the value of loading factor 0.97 . This is because the people and employees involved in the cooperative business are their own internal parties so that they are familiar with the affairs and internal information of cooperatives. The dry indicators of employees and employees who are quick to respond have a great value that is no less large, namely 0.87 and 0.84 so that the dry and fast response cooperative employees are also important in reflecting the people variables on this research.

\section{Place}

Varibel Place has four forming indicators, namely strategic attributes, cleanliness, comfort, easy-to-search layout. These four indicators have the value | t-Count | Larger than $\mathrm{T}$ table (1.96), so it can be said that these four indicators have a significant contribution to the promotion variable. The strategic place indicator is easily accessible and sought to have the most influence with the loading value of 0.94 and 0.85 factors. This is because the average cooperative customer answers a lot of agreed place indicators that are strategically accessible and searchable representing place variables. Cooperative comfort indicators are considered to be less representative of the place variable in this study because the loding value of the small factor is 0.57 .

7. Physical Evidence Varibel PHYSICSL evidence has five forming indicators, namely cooperative display attributes, parking availability, availability of trolleys, cooperative interiors and cooperative facilities. Indicators that have the value $\mid \mathrm{t}$-Count $\mid$ Larger than $\mathrm{T}$ table (1.96) is only four namely the attributes of cooperative display, availability of parking, interior cooperatives and cooperative facilities, so it can be said that these four indicators have a significant contribution to the variables Physical evidence. The cart/shopping cart availability indicator has a negative and insignificant 
contribution to the physical evidence variable with the value of loading factor- 0.05 and T-count-1.46, this is because many customers who answered the trolley are still not So important because their average purchase can still be held and enter the plastic bag. The attractive Interior of cooperatives has the greatest influence with the loading value of 0.96 factors. This is because the average cooperative customer has answered many agreed Interior indicators cooperative representing physical evidence variables.

\subsection{Analyzing the dimensions of marketing mix that affects the customer satisfaction of cooperatives.}

The effect of customer satisfaction on the loyalty of cooperative customers in South Tangerang city as well as factors that affect customer satisfaction is done by the analysis of Structural Equation Model (SEM). SEM analysis is done with a one step approach approach that is a component of measuring and structural models in the estimation simultaneously in a single analysis.

The SEM model analyzed in this study is a full hybrid model or a model of merging between the measurement models with structural models. Overall the relationship between the measurement model and the structural model is based on the theory. This research Model consists of seven variables of the exogenous latent, two endogenous latent variables, twenty-two variable indicators for seven variable latent exogenous and eight variable indicators for two endogenous latent variables.

The measuring Model shows the relationship between indicator variables with latent variables (exogenous latent and endogenous latent). The relationship shown in the measurement model is how strong the indicator variable is in measuring or reflecting each of its variable variables. The defined exogenous latent variables consist of Product Dimensions (X1), Price (X2), Process (X3), promotion (X4), people (X5), place (X6), Physical Evidence (X7).

The structural Model shows the connection between an exogenous latent variable and an endogenous latent variable.

The endogenous latent variables set out in this study are customer satisfaction (Y1) and customer loyalty (Y2). In addition to acting as an endogenous variable, customer satisfaction variables also act as exogenous variables, since in this research model in theory the customer satisfaction variables have a close relationship to customer loyalty variables. Each endogenous variable has an indicator variable that is to be of the flexibility.

\section{Goodness of Fit}

Before looking at the relationship between variables, first conducted an evaluation of the goodness of fit and significant model

SEM Analysis after the respesification shows the results of goodness of fit evaluation on this initial model has also resulted in the best match value. This table 4 indicates that all model match test criteria have been well-categorized (good fit). A good fit model means the model has been both in describing the data and the actual condition so that it can be adapted to the theory that it is based. 
Table 4 The result of a Respesification model match test

\begin{tabular}{lcccc}
\hline Goodness-of-Fit & Cutt-off-Value & Hasil & Kecocokan \\
\cline { 1 - 2 } Significance Probability(P-value) & & $\geq 0.05$ & 0.89 & Good Fit \\
RMR(Root Mean Square Residual) & $\leq 0.05$ atau $\leq 0.1$ & 0.11 & Good Fit \\
RMSEA(Root Mean square Error & & & \\
Approximation) & $\leq 0.08$ & 0.08 & Good Fit of \\
GFI(Goodness of Fit) & $\geq 0.90$ & 0.95 & Good Fit \\
AGFI(Adjusted Goodness of Fit & $\geq 0.90$ & 0.93 & Good Fit \\
Index) & $\geq 0.90$ & 0.98 & Good Fit \\
CFI (Comparative Fit Index) & $\geq 0.90$ & 0.94 & Good Fit \\
NFI (Normed Fit Index ) & & & & \\
\hline
\end{tabular}

The results of the reliability test to the variance extracted (VE) are mostly good model that has been imified resulting in the (table 5. This indicates that the indicator reliability of a construction or construct variables have a high consistency in reliability (CR) and extract variant or measuring the construction of the latencies.

\begin{tabular}{|c|c|c|c|c|c|c|}
\hline Variabel laten & $\begin{array}{c}\left(\sum \text { std }\right. \\
\text { Load })^{2}\end{array}$ & $\sum \mathrm{ej}$ & $\mathrm{CR}^{\mathrm{a}}$ & $\sum(\operatorname{std} \text { Load })^{2}$ & $\mathrm{VE}^{\mathrm{a}}$ & Reabilitas \\
\hline & 5,62 & 1,11 & 0,83 & 1,891 & 0,63 & \\
\hline & 3,03 & 1,4 & 0,68 & 1,83 & 0,57 & \\
\hline & 4,12 & 1,26 & 0,77 & 1,74 & 0,58 & \\
\hline & 10,56 & 1,28 & 0,89 & 2,73 & & \\
\hline & 9,12 & 1.62 & 0,85 & 2,37 & & \\
\hline Physical evidence & 12,96 & 1,67 & 0,89 & 3,34 & 0,67 & Good \\
\hline Customer Satisfaction & 2.46 & 2,81 & 0,47 & 1,19 & 0,30 & Good enough \\
\hline Customer loyalty & 2.99 & 0,49 & 0,86 & 1,51 & 0,75 & Good \\
\hline
\end{tabular}

${ }^{\mathrm{a}}$ Good reliability if $\mathrm{CR} \approx 0.70$ or $\mathrm{CR} \geq 0.70$ and $\mathrm{VE} \approx 0.50$ or $\mathrm{VE} \geq 0.50$.

Table 5 Reliability test of measurement model after imqualification

Produk Good Price
Process

Promotion

People

Place

$$
2,33
$$$$
0,42
$$$$
0,67
$$$$
0,22
$$$$
0,68
$$$$
0,59
$$

Good
Good enough

Good
0,59 Good

The results of SEM analysis after the model Respesification showed that most of the manifest and latent variables were valid describing the model.

A variable is said to have a good validity to the construct or its latent variables if the $\mathrm{T}$-value value is $\geq 1.96$ in real-level $\alpha=0.05$ and the value of standardized loading factor $\geq 0.3$ (Igbaria et al. 1997 in Wijanto 2008). Validity indicates that variables on the model are capable of measuring what should be measured or the model capable of 
explaining the relationships between variables. The model's T-value diagram Path can be overhagged in Figure 1.

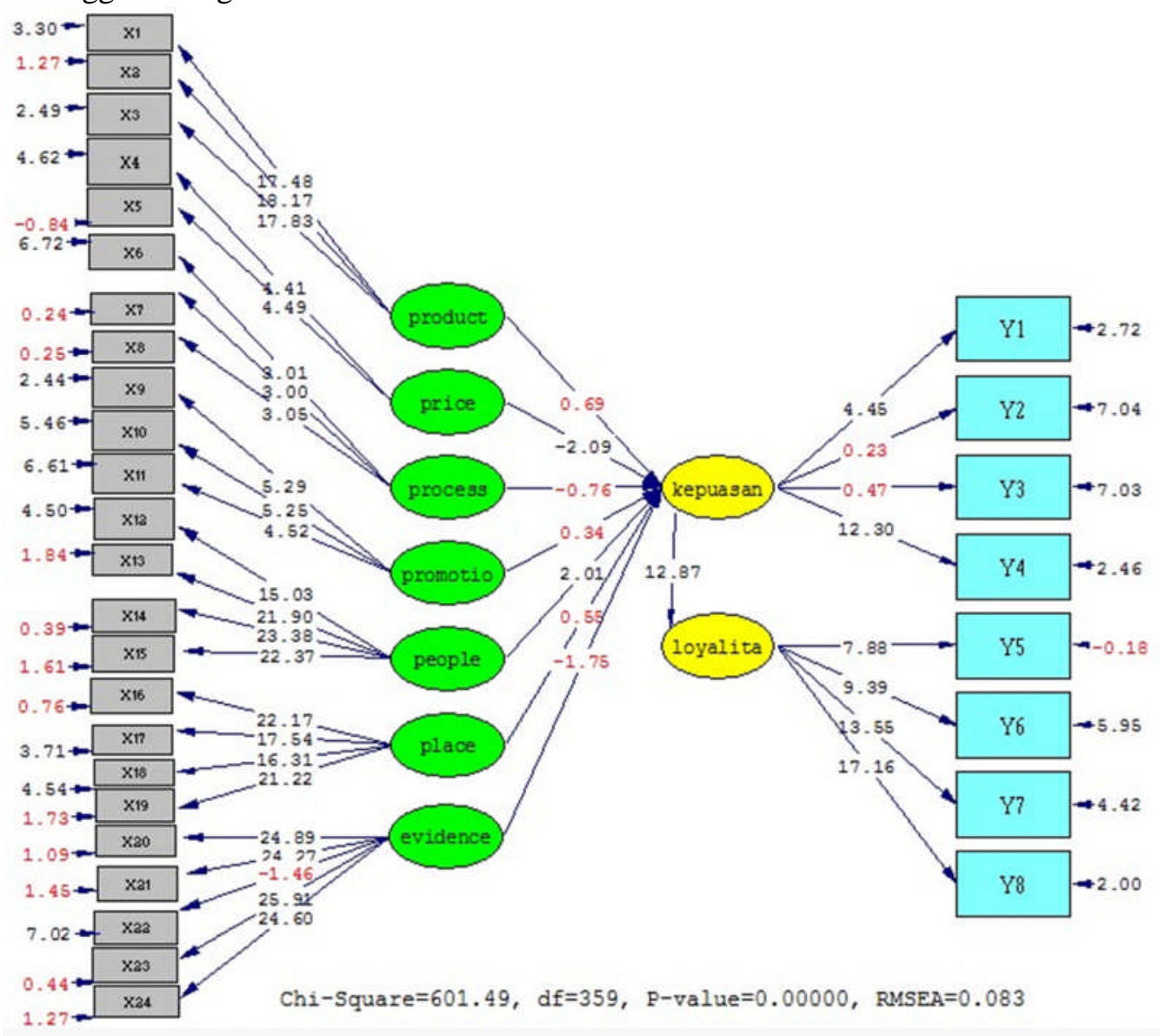

Figure 1. Path Diagram T-value model effect satisfactionCustomers towards cooperative customer loyalty in the citySouth Tangerang

\subsection{Analyzing the influence of customer satisfaction towards customer loyalty cooperatives.}

Based on Model 3, it is known that from seven dimensions a significant mix of marketing affects the customer satisfaction of cooperatives in South Tangerang city only Price $(\gamma=-0.32)$ and people $(\gamma=0.92)$.

Variable price has a negative influence on customer satisfaction means what if there is a price increase then the satisfaction of the support will decrease. The people variable has the greatest influence on customer satisfaction meaning what if performance, the friendliness of the people involved in the cooperative increases then customer satisfaction will increase. 


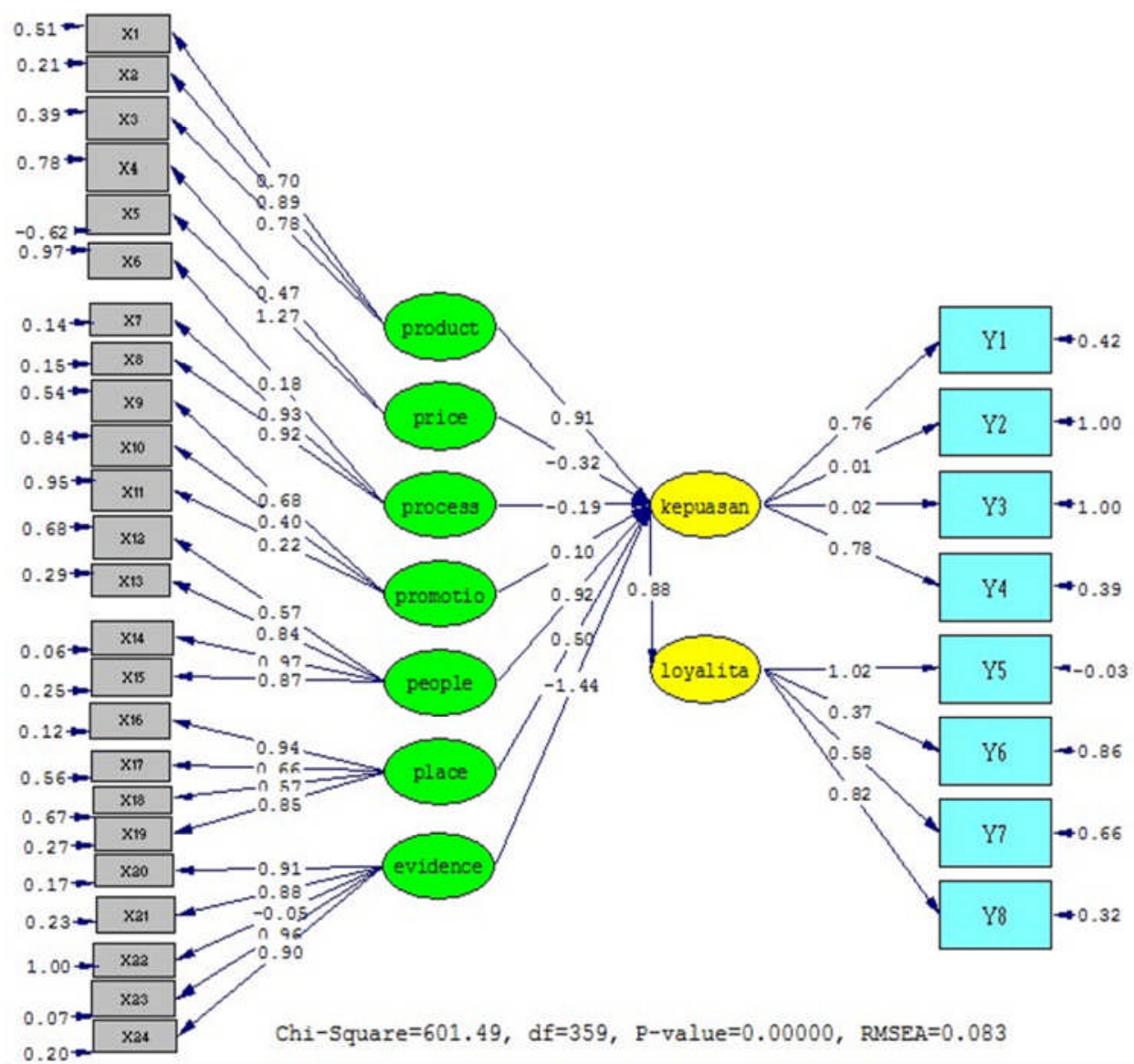

Figure 3 Path diagram Standardized solution model influence customer satisfaction towards customer loyalty cooperative in South Tangerang city

Varibel products can not form the customer satisfaction of cooperatives because the value of the black has not been significant even the value of loading large factors. This is not in accordance with previous research which suggests that the product has the greatest influence in shaping the satisfaction that will further form customer loyalty (Aryani \& Rosinta 2010; Gunawan 2015). The products that are sold cooperatives in the city of Tangerang is still not very fulfilling the needs and desires of customers so that it has not had a significant value on customer satisfaction.

Varibel process on this research has not been significant in the process of forming customer satisfaction, because in cooperative effort process consumption is not a major thing.

Varibel promotion, place and physical evidence on this research also have not been able to form the customer satisfaction cooperative, because its Tcount value is not significant. This is because the promotion done cooperative business in South Tangerang city has not been so visible, the location is also not very strategic and physical evidence has not been adequate. In fact, according to previous research physical evidence becomes indispensable for customers because customers have difficulty in assessing the true 
quality of an intangible service, and will be easier to assess the real components of Service Offerings (Zeithaml \& Bitner 2000).

Less promotional activities also affect the significance of the promotion the in customer satisfaction. It is similar to the research of Gunawan (2015) where the cooperative effort in the site researched only promoted through the signage and social media Twitter. The nameplate used by the cooperative has a less attractive form with a small size and less attractive color, so it is not enough to attract visitors to pay attention to the signboard. It is also happening in the cooperative in South Tangerang City, the board of cooperatives are less attractive and small in size.

Customer satisfaction is an endogenous latent variable as well as a intervening variable that plays a role in giving effect to the formation of endogenous latent variable customer loyalty. Based on the results of the test, the latent variable endogenous satisfaction has a value | thitung | Larger than the T-table (1.96) of 12.87. It means customer satisfaction significantly affects customer loyalty. The value of the resulting construct coefficient also shows a positive value of 0.88 . This indicates that increased satisfaction within the customer has the potential to influence the increase in customer loyalty to cooperatives. The results in this study in accordance with previous research showed that customer satisfaction has a positive and significant influence on customer loyalty (Aryani \& Rosinta 2010; Gunawan 2015).

The results of SEM measurements show significant and positive customer loyalty influenced by customer satisfaction. In other words, cooperative efforts in South Tangerang city should be managed based on the principles of more effective marketing mix. The growth of cooperatives in Indonesia has an increasingly strict business competition. The cooperative effort in Indonesia will come back forward if its human resources (people) are built on an ongoing and gradual basis. One way to create a competitive advantage through improving customer satisfaction and loyalty services. By improving the marketing mix will create a loyal customer so that it will potentially increase the number of cooperative businesses that are able to compete in today's globalization era.

\section{CONCLUSION}

Structural Equation Model (SEM) results show the customer satisfaction of cooperatives in South Tangerang city is most influenced positively and significantly by the dimensions of the people marketing mix. The cooperative business in Indonesia will return forward if its human resources (people) are built continuously and gradually. SEM analysis also shows that customer satisfaction will influence the loyalty of cooperative customers, so that in order to stay forward and able to compete cooperative effort should be able to build customer loyalty by improving from the side of marketing mix product, promotion, place, process, physical evidence. 


\section{REFERENCES}

Annisa AR. (2014). Pengaruh Kualitas Pelayanan Jasa Verifikasi Impor terhadap Kepuasan dan Loyalitas Pelanggan di PT Surveyor Indonesia (Persero). thesis. Bogor: Institut Pertanian Bogor

Bloemer, J. and Odekerken-Schroder, G. (2002). Store Satisfaction and Store Loyalty Explained by Customer and Store Related Factors. Journal of Consumer Satisfaction, Dissatisfaction and Complaining Behaviour, 15, 68-80.

Dmour HA, Zu'bi ZMFA, Kakeesh D. (2013). The Effects of Service Marketing Mix Elements On Customer-Based Brand Equity: An Empirical Study On Mobile Telecom Service Recipients in Jordan. International Journal of Business and Management, 8.

Griffin J. (2005). Customer Loyalty. Diterjemahkan oleh: Dwi Kartini Yahya. Jakarta: Erlangga.

Hurriyati R. (2005). Bauran Pemasaran dan Loyalitas Konsumen. Bandung (ID): CV.Alfabeta.

Kotler P, Amstong G. (1999). Prinsipprinsip Pemasaran Edisi 12 Jilid 1. Diterjemahkan oleh: Bob Sabran. Jakarta (ID): Erlangga.

Li ML, Green RD. 2011. A Mediating Influences On Customer Loyalty: The Role of Perceived Value. Journal of Management and Marketing Research, 2.

Lovelock CH, Wright LK. (2004). Manajemen Pemasaran Jasa. Diterjemahkan oleh: Agus Widiyantoro. Jakarta: PT Index.

Lupiyoadi R, Hamdani A. (2006). Manajemen Pemasaran Jasa. Jakarta: Salemba Empat.

Media detik.com. Program Koperasi Di Kota tangerang Selatan. https://finance.detik.com/beritaekonomi-bisnis/d-3675547/programkoperasi-ditangsel-diapresiasi

Muala AA, Qurneh MA. (2012). Assesing The Relationship Between Marketing Mix and Loyalty Through Tourists Satisfaction in Jordan Curative Tourism. American Academic \& Scholarly Research Journal, 4.

Parasuraman A, Zeithaml VA, Berry LL. (1985). A Conceptual Model of Service Quality and Its Implication for Future Research. The Journal of Marketing, 49.

Raab G, Ajami RA, Gargeya VB, Goddard GJ. (2008). Customer Relationship Management: A Global Perspective. England: Gower Publishing Limited.

Rahmati F, Falahati A, Jamshedynavid B. (2013). The Study Impact of Internal Marketing On Customer Loyalty (Case Study: Iran Insurance Company-Kermanshah Province). International Research Journal of Applied and Basic Sciences, 4.

Raphel M, Raphel N, Raye JS. (2007). Winning Customer Loyalty. Jakarta: PT Gramedia Pustaka Utama.

Wibawa BM, Sumarwan U, Dewi F. (2014). Customer Satisfaction Analysis for HydroVac Vaccine (Case Study on Catfish Farmers in Kabupaten Bogor). The International Journal Of Business \& Management, 21.

Wijanto SH. (2008). Structural Equation Modelling dengan LISREL 8.8. Yogyakarta (ID): Graha Ilmu.

Zeithaml VA, Bitner. 2000. Service Marketing: Integrating Customer Focus Across The Firm Secind Edition. New York: McGrow-Hill Education. 